\title{
The Impact of Translation Shift and Method on Translation Accuracy Found at Bilingual History Textbook
}

\author{
Kammer Tuahman Sipayung \\ University of HKBP Nommensen, Indonesia \\ Email: kammertuahmansipayung@gmail.com
}

\begin{abstract}
Well-translated bilingual history textbook can be as a well source of language knowledge. The purposes of this research were to figure out the dominant translation shift, method and the impact of dominant shift and method on accuracy translation aspect. The researcher used descriptive qualitative method to figure out the purpose of research. There are two kinds of data in this research: affective and objective data. The affective data are from key-informants in the form of scale. Objective data are from bilingual history textbook choosen randomly sampling in the form of words, phrases, clauses, sentences and text. The findings of this research shows that 1) The dominant translation shift is unit shift $58,33 \%$, structure shift: $30 \%$, class shift: $7,77 \%$ and intra-system shift: $3.88 \%$. 2) The dominant translation method is free translation: $57.57 \%$, communicative translation: $19.69 \%$, adaptation translation: $13.63 \%$ and semantic translation method: $9.09 \%$. 3) The impact unit shift and free translation method influence the lack accuracy of translation level: 2.38 . There are $60 \%$ from the bilingual history textbook is lack accuracy of translation.
\end{abstract}

Keywords: accuracy; bilingual; method; shift; translation quality

\section{INTRODUCTION}

Translation is the easiest way and alternative solution to accelerate the knowledge and technology in development country like Indonesia. Source of knowledge are dominant written in source text (English) while most Indonesian are lack in English. In order to accelarate the knowledge and technology, million foreign books are translated into bahasa. Accordance to the statement above, Abrams (2015) states that there are 1.400 publishing houses in Indonesia which publish around 24.000 titles of foreign books per year. It is the reason why translation get a great attention in translation research.

Translation quality assessment (TQA) is the main attantion on translation studies. The purpose of TQA is to measure the quality of Target Text (TT), whether it has been achieve or not. House (2015: 21) states that equivalence is the core concept in translation quality assessment. In addition, Sajarwa (2017: 159) states that, in translation, equivalence is negotiated and transactioned. In line to the statement above, Reiss $(1968,1971,1973)$ in House $(2015: 14)$ states that function and the text type of the source text determine the quality of translation. It means that the TQA is negotiated and transactioned in translation quality.

Different text type uses the same term but different in meaning. Such as, massa in the social text reffer to people, while in science reffer to weight of things. It is one problem of the complex task of translator, to find the equivalence. Nida and Taber (1969: 22) translator is placed to find the equivalence which is not always appropriate in the target language. It means that translator creativity in negotiation and transaction is needed to solve the inappropriate or nonequivalence in target text. In negotiation on meaning, translation shift and method cannot be avoided as consequence to achieve better translation accuracy.

There are three parts of translation quality, 
namely accuracy aspect, acceptability aspect and readability aspect, Nababan (2012). Based on the three aspects above, the researcher choose the accuracy aspect as the instrument of translation quality in this research. The consequence of translation shift and method on accuracy aspect need to investigate in bilingual history textbook that the students used. The reseacher choose this book as source of data because of the researchers' observation. Generally, the team of translator ommiting and adding (shift) TT from the original.

Translator used such kind shift of translation to achieve the accuracy of translation. The shift of translation will be done by the translator depend on his competence on ST and TT. It means that translation shift and translator competences have a significant correlation. When a translator have a

basic knowledge on translation shift, characteristics of both languages, translation direction and lot of practices finally satisfied translation can be achieved. Popovic (1979: 78) in Juliati (2013: 23) states that individual method of translation is determined by the presence or absence of shift in various layer of translation. It means that the presence or absence of shift in translation can be called as a method in transferring the meaning.

In this era, most of bilingual textbooks are used at school from kindergarden upto senior high school. The research about translation accuracy on bilingual translation need tobe done continiously. Because by reading a bilingual textbook can increase the readers vocabulary. Medikawati (2012: 38) states that books-foreign language books equipped with translation that older children can draw their interest in a wider reading community. Bilingual textbook is a strategy to accelerate knowledge in school. The teacher can create the community of reading bilingual textbook as a source of language knowledge.

The objectives of this research are 1) to figure out the dominant translation shift and method found on bilingual (Indonesian-English) textbook entitled History for Junior High School Year VII written by Siswosudarmo Radjiman and translated by himself and team in 2012 and 2) to find the impact of dominant shift and method on accuracy of translation. In order to achieve the research objectives as stated above, the researcher used qualitative-descriptive method with embedded case study research design. Based on Bodgan and Biklen's (2007: 4) characteristics of qualitative research design as naturalistic, descriptive data, concern with process, inductive and meaning. In this research, the objective data is natural and the affective data is descriptive. The rate of key-informant help the researcher to describe a phenomena of translation accuracy. It is the reason why this research categorized as qualitative-descriptive research. While to analyze the data, the researchers used interactive data analysis based on Miles, Huberman and Saldana (2014: 3). The researchers focused and selected to the pair text which experienced translation shift and method. the researcher made the data become stronger through displaying the objective and affective data. Finally the researcher organized and compressed the information that allows to draw the conclusion. The description of interactive data analysis is described as the following figure.

Figure 1.

Interactive Analysis Process

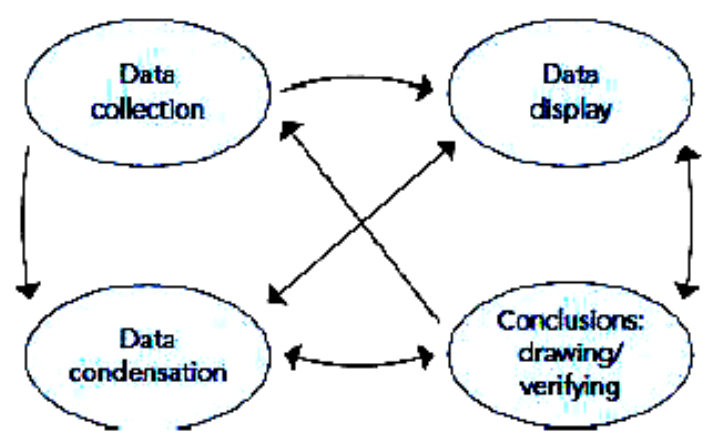

Miles, Huberman and Saldana 2014:3

There are two source of data in this research. The first is primary data or objective data from the content of target text. This data is collected through content analysis in the form of words, phrases, clauses and sentences to represent translation shift. To represent data, the researcher used random sampling technique. Williams and Chesterman (2002: 96) recomend random selection to claim that your data is representative, in addition to that, they state that, random sampling avoid bias in the field of statistic. This data were figured out (in statistic) the dominant shift and method in translating history bilingual textbook which is published by Yudhistira for grade VII written by Radjiman and translated by Radjiman team.

The last is secondary data or affective data in the form of rate from inter-raters-reability (key informant). This data is collected through questionnaire, depth-interview and forum group 
discussion (FGD). After knowing which kinds of shift and method is dominant, the researchers investigated the impact of dominant shift and method on translation accuracy. This research is important to improve the translation accuracy in further bilingual textbook and to develope the competence of translator. While the usage (students and teachers) of bilingual history textbook will improve their knowledge by reading well translated.

Catford (1965:73) states that, there are two major of translation level shift and category shift. In line to that, He defines category shift as structure shift, class shift, unit shift, and intrasystem shift. Such translation shift are quite common on translating language. Newmark (1988: 85) describes that, shift is translation procedure involving a change in the grammar from SL to TL. in addition Munday (2004: 28) states that, a shift is said occur if, in a given TT, a translation equivalent other than the formal correspondence occurs for a specific SL element. It means that shifts are all mandatory action and optional one. Based on it, the researchers assumed that it's important to investigate the translator mandatory by measuring the translation accuracy. The accuracy on translation cannot be separated from translator dependence and competence on translation shift.

Similar to translation shift, translation method are also optional and mandatory action of translator. Method is a particular way to do something, in this context is a way to translate a text. Generally, there are three steps in translating process, analyzing the ST, transfering and reconstructing. Molina and Albir (2002: 507) Translation method refers to the way a particular translation process is carried out in terms of the translator's objective, i.e., a global option that affect the whole text. In addition to that, Molina and Albir (2002: 507-508) describes that there are several translation method that may be chosen, depending on the aim of the translation: interpretative-communicative (translation of the sense), literal (linguistic transcondification), free (modification of semiotic and communicative categories) and philological (academic or critical translation). Neubert (2000: 3) states that there are seven factors are present in all the process involved in translation such as complexity, heterogenity, approximate, non-finate, creative, situasionality and historicity.
While, based on Newmark (1988: 45) about translation method devides into two orientation; SL orientation and TT orientation. This description can be seen on V diagram. Translation method which are oriented on SL: word for word translation, literal translation, faithful translation and semantic translation. While, translation method which are emphasis on TL : Communicative translation, Idiomatic translation, Free translation and adaptation. In this article, the researchers focused and applied the translation method based on theory of Newmark. This theory is more comprehensive.

The translator's control is affected to the quality of translation. Shuttleworth and Cowie (1997), accuracy is a term used in translation evaluation to refer to the degree of correspondence between the translated and original text. Larson (1984) accuracy in representing the meaning of the original text and using natural idiomatic expressions in the receptor language are the primary goals of the translator. Further, Larson (1984: 490) states the main objectives of accuracy test are as follows; a) to check the equivalence of information in a text, b) to find another problems by comparing ST and TT, after he/she is sure about the existence of the information need. From the statements above, it can be concluded that, accuracy test can be achieved by translator's control and competence.

The accuracy of TT depends on translator competence. The accurate TT produced by well competence of translator. Newbert (2000: 6) formulates five parameters of translation competence such 1) language competence, 2) textual competence, 3) subject competence, 4) cultural competence, and 5) transfer competence.

In line to that, Eva Hung in Nunning (2010) states that Language competence, in the sense of being bilingual, is not enough, unless it is also matched by a person"s being bicultural. Munday (2004: 351) states that textual competence is the ability not only to apply the lexicogram - matical rules of a language in order to produce well-formed sentences, and not only to know when, where and to whom to use these sentences, but to know how to make the sentence play a role within a sequence that is eventually part of a well-formed text, discourse and genre. From the statement above about competence place the position of translator play a crucial role in translating. The accuracy meaning of TT produced by well competence of translaor and vice versa. 
The accuracy of meaning can be checked by a semantic comparison of TT and ST. Larson (1984) the comparison may include factors such as omissions and additions in the translated text, zero meaning (when the form used does not communicate any meaning at all) and differences in meaning. Khomeijani Farahani (2005) believes that accuracy refers to the extent to which the writer translates a text accurately and precisely. According to him, there are two ways to determine the degree of translation. The first is to compare the key words, how close the two sets vocabulary between ST and TT are. The second ways is to re-translated the TT that have been constructed by examine again how close the reconstructed text is to the ST. The purpose both of ways are to produce the acceptable terms of accuracy criteria so that identical ST transfer into TT can be achieved.

Oxford Advanced Learner's Dictionary (2005: 133), bilingual is defined as "using two languages; written in two languages". Medium for entertaining and medium for learning are function of bilingual textbook. The depth-research on bilingual textbook is important to conduct in order to achieve the best accuracy of translation. It is apprehensive that inaccurate have an impact on students' quality on language and particular knowledge in bilingual textbook itself.

Based on the description above which state the independence of translator to chose translation shift and method in order to produce a high accuracy on translation. Accurate translation can be achieved through translating meaning that equivalent on TT not the form. The meaning must be translated based on TT culture and norm of Indonesian students who grade VII at Medan as a target reader. Accordance on reasons and research objectives above, the researchers formulate the research title as follow "The Impact of Translation Shift and Method on Translation Accuracy Found at Bilingual History Textbook" in this article.

\section{FINDINGS AND DISCUSSION}

After reading, comparing and processing of reducing data (interactive data analysis) the researchers took 136 pairs of translation as a sample of data. The sample of pair sentences above experienced the shift of translation and translation method. The sample above is rated by accuracy inter-raters. After analyzing the data from bilingual history text book which is used by several grade VII in Medan, the calculation of translation shift (structure shift, class shift, unit shift and intra-system shift), translation method and accuracy level can be shown in the following findings:

\section{Translation Shift}

After doing the analysis overall data (136 pairs of translated text) about translation shift from bilingual history textbook. It is found that the dominant shift (the percentage) is unit shift $58,33 \%$, structure shift is $30 \%$, class shift is $7,77 \%$ and the last is intra-system shift is 3,88\%. The description of translation shift can be seen in the following Figure.

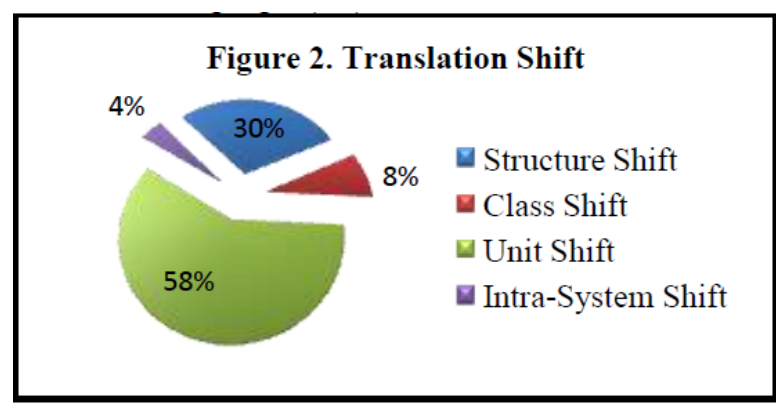

From the description above, translator's tendency is unit shift to solve the non-equivalence in his/her independence. Of course, unit shift as dominant shift on source data played a big role in translation accuracy, whether it is accurate, lack of accurate or not accurate. These posibilities impact are the core of this article that the reseacher investigated. Here are some examples of data analysis on translation category shift which can be divided into four types; structure shift, class shift, unit shift and intra-system shift. The concept of shift in this article is reffers to the theories of Catford.

\section{Structure shift}

There are 54 texts translated into English by using structure shift strategy. Here is the example of structure shift which is found in the bilingual history text book.

ST : Berburu, bercocok tanam, dan tinggal di

$$
\text { C }
$$
gua-gua, harus mereka lakukan untuk $S \quad P$ dapat bertahan hidup (4) C

TT : They lived from hunting and farming. (5) $\begin{array}{lll}S & P & C\end{array}$

From the example above, the structure of source text is $\mathrm{C}+\mathrm{S}+\mathrm{P}+\mathrm{C}$ and translated into $\mathrm{S}$ $+\mathrm{P}+\mathrm{C}$ in target text structure. Structure shift is 
occured in the words changing of words sequence in sentence. The structure shift is occured because the changes of structure sequences in the sentence. This shift can be optional and obligation, it depends on the translator's option or a certain linguistics style. Reconstruction is done by the translaor into TT is based on his/her competence. The absence or presence of translation shift is based on the translator individual strategy.

\section{Class shift}

There are 14 texts translated into English by using class shift strategy. Class shift is occurred if there is a change in level of class word in translation. Generally in English there are eight classes of words (part of speech) namely; noun, verb, adjective, adverb, preposition, pronoun, conjunction and determiner. Noun, verb, adjective, adverb are categorized major classes while preposition, pronoun, conjunction are minor classes. Classes of word in every language system can be differing after translating from source text into target text. for the example, in English can be found the class of adverb which can be translated into phrase in Indonesian, such as slowly is translated into dengan lambat. Similar thing also happened when translating determiners of English into Indoneian. The following is example of class shift which can be seen:

: Kerajaan Sunda mangalami keruntuhan pada tahun $1579 \mathrm{M}$ akibat serangan pasukan Islam dari Banten. (92) : Sunda fell in 1579 after attacked by Banten. (93)

The finding above shown us how class shift occured in translation. The source text akibat (noun) is translated into target text become after (adverb). The class of noun (akibat) is translated into adverb (after).

\section{Unit shift}

$58.33 \%$ text is translated into TT with unit shift strategy. The change of rank is called unit shift. The rank of languages is started from smallest to the highest and vice versa such as morpheme, word, phrase, clause, sentence and text. Unit shift is departures from formal correspondence in which the translation equivalent of a unit at one rank in the source text is a unit at a different rank in the target text.

The following example is unit shift can be seen in the following finding :

\section{ST : :bangsa Indonesia (8) \\ TT :Indonesian (9)}

The unit shift (dawn rank shift) is occurred in the finding text above. The ST in the form of phrase (bangsa Indonesia) is translated into TT in the form of word (Indonesian). The unit shift is the dominant shift, which can be found from the source of this data. There are 105 or $58,33 \%$ unit shift which is found in the bilingual history text.

\section{Intra-system shift}

The lowest shift as a translators' strategy in translating is Intra-system shift; 7 pair of translated text. Intrasystem shift is the shift, which is occurred internally, whether the ST and TT system is approximately correspond formally as to their constitution, but when translating, involve selecting process of a noncorresponding term in the TL system. The following example is intra-system shift can be seen in the following finding:

ST : Diluar Jawa, dipusat-pusat kota dagang dan Kerajaan Islam juga didirikan pondokpondok pesantren.(168)

TT : Outside Java, in trading hubs and Islam Kingdoms there also built pesantren. (169)

From the finding above shown us the intrasystem shift in the concept of plural form. Meanwhile, another concept of intra-system shift is found in the analysis data, such as a) the usage of noun as a reference of generic, b)the usage of plural noun after plural determiner, and c) the differences concept of tenses. This kind of shift is 3,88\%.

\section{TRANSLATION METHOD}

After doing the analysis about translation method from bilingual history textbook. It is shown that free translation is dominant method that the translator used to translate bilingual history textbook which is used by grade seven namely $57,57 \%$, communicative translation is $19,69 \%$, Adaptation is $13,63 \%$, semantic translation is $9,09 \%$ and the translator did not applied literal translation, faith translation, idiom translation and word for word translation in translating bilingual history text book which is used by grade VII in Medan. For more explanation, it can be seen in the following description in the figure 3. 


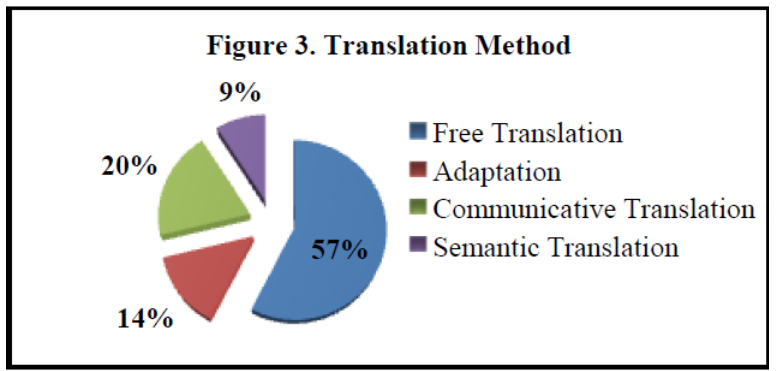

The highest percentage (dominant) translation method is free translation : $57,57 \%$ or 38 data. This method played a big role on translation accuracy on bilingual history textbook that used by grade VII at Medan. There is one from three posibilities option as the impact of dominant translation method on translation accuracy, namely; free translation method cause the high accuracy of translation quality, lack of accurate and not accurate. It is the core finding in this research. The dominant method contributes a negative or positive impact on translation accuracy.

\section{TRANSLATION ACCURACY}

Generally, The average of accuracy scale from the inter-raters is 2.38 . It means that more translated text is lack of accurate. The accuracy aspect can be achieved by restructuring and re-express the meaning again. The accurate of translation from the textbook is 20 data or $40 \%, 58 \%$ or 29 data is lack of accurate while there is $2 \%$ or 1 data which is not accurate. The description of the accuracy on translating history textbook can be seen in the following table:

Table 1.

The Total of Accuracy Inter-Raters

\begin{tabular}{|c|c|c|c|}
\hline & \multicolumn{3}{|c|}{ The total of accuracy inter-raters } \\
\hline Scale & 3 & 2 & 1 \\
\hline Criteria & Accurate & $\begin{array}{c}\text { Lack of } \\
\text { accurate }\end{array}$ & $\begin{array}{c}\text { Not } \\
\text { accurate }\end{array}$ \\
\hline Quantity & 20 & 29 & 1 \\
\hline Percentage & $40 \%$ & $58 \%$ & $2 \%$ \\
\hline $\begin{array}{c}\text { Accuracy } \\
\text { scale }\end{array}$ & \multicolumn{3}{|c}{} \\
\hline Total of Data & \multicolumn{3}{|c}{50} \\
\hline
\end{tabular}

More than half of translated text (60\%) categorized lack accurate and need to evaluate the process of translation again or changing of term again. From the finding of this research, only $40 \%$ which categorized accurate in this translation. From this obviously condition, translator need tobe carefull in selecting a particular term, method and shift in translation to decrease the lack of accurate level or aspect on translation.

Furthermore, some examples about accuracy aspect of translation will be written from the source data. Here is the example of accurate translated text.

\section{: Agama Budaha Hinayana berkembang} cukup pesat di kerajaan Kaling. Salah satu buktinya adalah datangnya biksubiksu dari Cina seperti Hui-ning dan pembantuya, Yun-ki. Kedatangan mereka yakni untuk belajar bahasa Sanskerta dan agama Budha Hinayana kepada sarjana agama Budha hinayana di Kaling bernama Janabadra (johna Patolo)(58)

: Buddha Hinayana rapidly developed in Kaling, one of the evidences was Chinese monks like Hui-ning and his assistant, Yun-ki. They came to learn Sanskrit and Buddha Hinayana to Buddha Hinayanan scholar in Kaling named Janabadra (Johna Potolo). (59)

Translated text above applied two methods, namely adaptation and free translation. Translator adapt some terms into TT, such as Hinayana and Janabadra. While the rest is translated by using free translation. Based on the three accuracy inter-raters, it is categorized accurate.

The example which is categorized lack of accurate. It is important to restructure and re-express the process of transfering meaning again. The example of lack accurate translated text as follow:

ST

: Dalam bidang Pemerintahan,Daendles membatasi kewenangan kerja para pegawainya. Hal itu dimaksudkan agar mereka tidak terjerumus dalam tindakan korupsi. Dandles kemudian membagi Pulau Jawa dalam sembilan keresidenan yang berada di bawah pengawasan Pemerintah pusat. Selain itu, sebagai penguasa lokal, para Bupati dijadikan pegawai pemerintah dengan gaji dan pangkat yang sesuai dengan ketentuan. (200)

TT : Daendles limited the authority of his workers to avoid corruption. Daendles divided Java in 9 residencies under the 
central government supervision. Besides, as a local ruler, the regents were made as government employee with certain salary and rank. (201)

The translated text above is categorized accurate but some omission of message from source text into target text is not important to apply. Dalam bidang pemerintahan... and hal itu dimaksudkan agar... is omitted in TT. This omission make the TT is lack of accurate based on the three accuracy inter-raters. The omission is potentially to delete the meaning.

The example of not accurate bilingual history textbook can be found in the following example:

ST : Taktik pecah belah selalu menjadi senjata pamungkas Belanda. Devide et Impera berarti pecah belah dan kuasai. Setelah mengadu domba, Belanda dapat menguasai dengan mudah. Taktik licik ini diambil jika Belanda kewalahan dan terdesak menghadapi perjuangan bangsa Indonesia. (232)

TT : Explain the background of colonialism resistances. Why do you think those resistances often failed? (233)

Based on the three inter-raters, the example above is not accurate. Translator applied free translation method without consideration on meaning. Translator were fail to discover the meaning and to re-express the meaning or transfer the meaning into TT. The team of translator was lost control, this phenomena affect on the accuracy aspect of translation. The lost control reflect the lack of evaluation in term of correspondence between ST and TT. The translators did not check the equivalence of pairs translated text. They did not compare the existence information in ST and TT.

\section{CONCLUSION}

Translation is the process to find the equivalence meaning between ST and TT. Shift and method are strategy that the translator use to achieve good translation. Accoradance to that, the aims of this research are to figure out the impact of translation shift and method on translation accuracy aspect. The result of this qualitative-descriptive research shows that the lack accuracy of translation because of the lack competence on usage of translation shift and method. Inappropriate of translation shift and method played a negative role on translation accuracy can be seen in the table 2.

From the table 2, it can be concluded that unit shift (US) is a dominant shift $(58,33 \%)$ in the translation process in bilingual history textbook which translated by Rajiman and team. The impact of unit shift (US) influence the lack accuracy aspect on translation quality. On the other side, Free translation method is a dominant method $(57,57 \%)$ that the translator use. The negative impact also occurred on translation accuracy when dominant free translation method is applied by the translator. It means that the orientation of translators focused on Target language (TL emphasis). There are $60 \%(58 \%+2 \%)$ of TT or more than a half from TT is lack accurate. From the statement above, it can be summarized that, the dominant unit shift and free translation method influence to the lack accuracy of translated text in the bilingual history textbook that used by grade VII at Medan.

From the table above, the translators need to choose another shift except unit shift and another method except free translation method to make the TT become accurate. Unit shift is often to omit and to add the information or meaning (word, phrase, clause, sentence, text) from ST to TT that make the information become inaccurate. Class shift need to use often to decrease the lack accuracy of translation in this bilingual textbook. Semantic translation and communicative translation method need to apply more often than free translation method in bilingual history textbook in order to achieve an accuracy on translation. The application of free translation method in this bilingual history textbook made several meaning in target text is omitted from the source text.

Well-translated text from ST to TT played an important role to improve students' knowledge about language. The students' knowledge about language can be improved through reading. When students read bilingual textbook can be as a source of knowledge on language. Students of grade VII or other students who use bilingual textbook can develope their sub-skill of English, comprehension and skill of English language. Contrary to that, bed translated bilingual history textbook is a poisonous to the student's language knowledge. Not only well competence on language system and culture both of languages (ST and TT) but also well trainee is important in translating process. Christiane Nord (1997: 39) states that, teachers who have been trained as translators or who have worked in professional environments usually know that different 
Table 2

The Conclusion of Translation Shift, Method and Accuracy

\begin{tabular}{|c|c|c|c|c|c|c|c|c|c|c|}
\hline \multicolumn{4}{|c|}{ Translation shift } & \multicolumn{4}{c|}{ Translation Method } & \multicolumn{3}{c|}{$\begin{array}{c}\text { Accuracy of translation } \\
\text { scale }\end{array}$} \\
\hline SS & CS & US & Is.S & FT & A & CT & ST & 3 & 2 & 1 \\
\hline 54 & 14 & 105 & 7 & 38 & 9 & 13 & 6 & 20 & 29 & 1 \\
\hline $30 \%$ & $7,77 \%$ & $58,33 \%$ & $3,88 \%$ & $57,57 \%$ & $13,63 \%$ & $19,69 \%$ & 9,09 & $40 \%$ & $58 \%$ & $2 \%$ \\
\hline
\end{tabular}

contexts call for different translation solutions; they have an intuitive awareness of functionalism. It means that part-time translator such as teacher who teach history or other subject have a global opportunity become a translator if he/she have been trainned as translator.

It is needed to give a special translation trainee to the translator of bilingual history textbook, which is published by Yudisthira especially to the translators of bilingual history textbook grade seven. The role of government and the expert of translation is the most important to achieve better competence on translator. Indirectly, students as the usage of bilingual textbook will get better linguistic competence and knowledge by reading well bilingual translated text. The scope of this research is about translation shift and method on bilingual history textbook. It means that to the next researchers is suggested to conduct a similar research on other bilingual textbooks, which is used by kindergarden, elementary, junior high school, and senior high school about the impact of cohesion and coherence shift on translation quality based on other theories. The implication of this research is addressed to the translators (Radjiman and team) of history bilingual textbook especially and generally is addressed to the whole part-time and free translator to follow the trainee on translation field to improve a better competence on translating finally to produce high quality of translation, because well competence will produce well product. Hopefully, this research can be made as a reference to the next researcher in order to develop translation theory.

\section{ACKNOWLEDGEMENT}

The researchers' gratitude is delivered to Ristekdikti who give fund to complete this research. The next gratitude is delivered to Dr. Roswita Silalahi,M. Hum who gave the contribution to complete this article. The last thanks is delivered to the chief editor of HUMANIORA journal to publish this article.

\section{REFERENCES}

Abrams, Dennis (2015). Is Indonesia a Land Without Readers? Publishing Perspective. Retrieved on 12 July, 2017, from. http://publishingperspectives. com/ 2017/06/is-indonesia-a-land-withoutreaders/.

Bogdan and Biklen (2007). Qualitative Research for Education An Introduction to Theory and Methods 5th edition. Sanfransisco: Pearson.

Catford, J. C. (1965). A Linguistic Theory of Translation. Oxford: Oxford University Press.

Farahani, A. A. (2005). A framework for translation evaluation. Translation Studies, 9 (3), pp. 75-86.

House, J. (2015). Translation Quality Assessment. London and New York: Routledge.

Juliati (2013). Shift on the translation of English active constructions into Indonesian. UG Jurnal, Vol.7, No.01.

Larson, M. L. (1984). Meaning-based translation. London: University Press of America.

Medikawati, Julie (2012). Membual Anak Gemar dan Pintar Bahasa Asing. Jakarta: Visimedia.

Miles and Huberman (2014). Qualitative Data Analysis. United State of America; SAGE Publication, Inc.

Molina and Albir (2002). Translation Techniques Revisited: a dynamic and functionalist approach Meta: Journal des Trailucteursl Meta: Translators' Journal XLVIL No.4, pp. 498-512

Munday (2004). Translation: An advanced resource book. New York:Routledge 
Nababan,M.R., Nuraeni, \& Sumardiono (2012). Pengembangan Model Penilaian Kualitas Terjemahan. Kajian Linguistik dan Sastra, 24 (1), pp. 39-57.

Newbert, A. (2000). Competence in Language, in Languages, and in Translation, in C. Schäffner and B. Adab (eds.): Developing Translation Competence. Amsterdam, John Benjamins, pp. 3-18.

Newmark P. (1988). A textbook of translation. Hertfordshire: Prentice Hall.

Nida, E. A. dan C. Taber (1969). The Theory and Practice of Translation. Leiden: E.J. Brill.
Nord,C (1997). Translating as a Purposeful Activity. Manchester: St. Jerome Publishing.

Nunning (2010). Ideologi Penerjemahan dan Penerjemahan Ideologi. Diglosia, Vol. 2 (1).

Sajarwa (2017). Deconstructing Equivalence in the Translation of Text from French to Indonesian. Humaniora, Vol. 29, No. 2, pp. 159-168.

Shuttleworth, M. \& Cowie, M. (1997). Dictionary of translation studies. Manchester, UK: STJEROME.

Williams, J and Chesterman, A. (2002). The Map: A Beginner's Guide to Doing Research in Translation Studies. Manchester: St. Jerome Publishing. 